\title{
Factors Affecting Income of Pineapple Small Farmers: Case Study at Tangkit Baru Village, Jambi Province, Indonesia
}

\author{
Boris Kaido \\ Doctoral Fellow, Laboratory of International Development Studies, \\ Graduate School of Agricultural Science, Tohoku University, Japan
}

\begin{abstract}
This study was conducted in Tangkit baru village, Jambi Province, Indonesia. The Study area was selected purposively based on this village which has produced the highest pineapple conducted by small farmers in Jambi Province. This study aims to determine the factors that affect the income of a small farmer pineapple in Tangkit baru village. The study aims were analyzed in descriptive methods and multiple linear regression analysis. The number of respondents was taken in the Slovin method, with 42 respondents. Data collection used the interview method with the questionnaire conducted directly in the study area. The data were analyzed quantitatively, the results study showed that all variables affected the farmer's income, it was seen as a significance value of $0.000<\alpha 5 \%$. Partially, the variables that affect the farmer's income are field scale (X7) and labor factor (X6), while the variables that have no significant effect on pineapple small farmer's income are the land rent (X4) and fertilizer (X1).
\end{abstract}

Keywords: Farmers, Pineapple farming, Factors affecting, Income

\section{INTRODUCTION}

The agricultural sector has an important role in the Indonesia national economy in terms of national economic development. This can be seen from the contribution to gross domestic product, absorbing labor, food provider, energy materials, feed, industrial raw materials, and sources of income in rural communities. One of the superior products of horticultural crops, especially fruit, namely pineapple. Pineapple (Ananas comosus L.) is one of the leading fruit commodities in Indonesia. This refers to the amount of pineapple production which occupies the third position after bananas and mangoes. Besides being consumed in fresh form, the pineapple can also be processed into various products such as juice, jam, syrup and chips. Pineapple contains water, sugar, organic acids, minerals, nitrogen, protein, bromelain enzyme and all vitamins in small amounts, except vitamin D. Pineapple skin can be processed into syrup or extracted its liquid for animal feed, while fiber on the leaves can be processed into paper and textiles (Hadiati and Indriyani, 2008).

Tangkit baru village is the largest pineapple production area in Jambi Province, this commodity is the driving force of the economy and the main source of income for this region, pineapple cultivation in Tangkit baru since 1970. Almost all villagers work as pineapple farmers. Previously this village is a forest area with the conditions of peat soil that is inundated (Pratama, 2017).

Pineapple as an agricultural commodity often experiences price fluctuations, caused by an imbalance in commodity supply and demand. Although pineapple contributes to the economy of farmers, but with it constraints and price changes, there is a question that, will pineapple farming still be able to meet the economic needs of smallholder families in the future, then 
Improvement efforts of farmers' income and welfare face the problem of agricultural labor, narrow land area, and land rent and fertilizer prices which affect the revenue of pineapple farmers in Tangkit baru village.

The level of income and the factors that influence it become a benchmark the success of pineapple farming in this village and being able to exert the influence on the level farmers' income and welfare. Based on the description above, this study aims to find out the factors that affect the income of pineapple small farmers to improve the family economy of pineapple small farmers in Tangkit baru village.

\section{RESEARCH METHODS}

The study was conducted in September - October 2018 and June-July 2019 in Tangkit baru village, Jambi Province, Indonesia. The location was selected purposively based on this village has produced the highest pineapple production among the villages in Jambi province and carried out entirely by small farmers. This study aims to find out the factors that affect the income of pineapple farmers to improve the family economy of pineapple farmers in this village. The data used were primary and secondary data. Primary data is obtained by using structured interviews using questionnaires, while secondary data is obtained from literature studies. The population in this study were all pineapple farmers with 675 farmers and 42 samples determined by Slovin method. The analytical method used in this research is the descriptive and quantitative analysis. To analyze the level of income used the following formula, mathematically it can be written as follows (Soekartawi, 1995):

$$
\begin{gathered}
\pi=T R-T C \\
\pi=(P \times Q)-(T F C+T V C)
\end{gathered}
$$

Where:

$\pi=$ Farmer's income (IDR)

$T R=$ Total revenue generated from farming $(I D R)$

$T C=$ Total cost incurred from farming activities $(I D R)$

$P=$ Commodity price of the business $(I D R / K g)$

$Q=$ Number of commodities produce $(\mathrm{Kg})$

$T F C=$ Total fixed costs incurred in farming activities $(I D R)$

$T V C=$ Total variable cost incurred in farming activities (IDR)

While the variables to find out the factors that influence the income of farmers are 7 variables, then analyzed using multiple linear regression model and formulated as follows (Gujarati, 2006):

$$
Y=a+b 1 X 1+b 2 X 2+b 2 X 2+b 3 X 3+b 4 X 4+b 5 X 5+b 6 X 6+b 7 X 7+\mu
$$

Where:

$$
\begin{aligned}
& Y=\text { Pineapple farmer income }(I D R / \text { month }) \\
& a=\text { Intercept } \\
& X 1=\text { Fertilizer Cost }(\text { hectare } / \text { year }) \\
& X 2=\text { Herbicide Cost }(\text { liter } / \text { app }) \\
& X 3=\text { Flower stimulator }(\text { liter } / \text { app }) \\
& X 4=\text { Land } \text { rent }(\text { Hectare } / \text { year }) \\
& X 5=\text { Tools }(\text { App } / \text { year }) \\
& X 6=\text { Labor }(\text { Hour } / \text { year }) \\
& X 7=\text { Field scale } \text { (Hectare) }
\end{aligned}
$$


$A=$ Intercept

$b 1, b 2, b 3=$ Coefficients regression

$\mu=$ Error

Before using multiple linear regression, to get a good model, the variable should be free from normality, multicollinearity, and heteroscedasticity. After the variable has been freed from these properties, it is necessary to test the model parameters and variable parameters (Nazir, 2005).

The statistical test used is the F test, this test aims to find where the independent variables used together have a significant effect on the dependent variable (Sudrajat, 1985). To find out the partial effect of the independent variable on the dependent variable used the $T$ test, this test aims to determine whether the regression coefficients of each independent variable (X) used have a significant effect on the dependent variable (Y) (LIPI, 2014). The SPSS version 25 was used to analyze the quantitative data collected for this study.

\section{RESULTS AND DISCUSSION}

\section{Description of Pineapple Small Farmers in Tangkit Baru Village}

Tangkit baru is a village located close to the capital city of Jambi Province, but it is not supported by a high level of education. Based on table 1, most pineapple farmers in the study area were junior high school graduates of 52\%, while the age level of farmers is still productive, namely 41-55 years old reaching $62 \%$ and farmers are above 56 years old only $17 \%$. This condition implies that farmers still have the opportunities to increase income of pineapple farming. The average farmers' experience in farming cultivating of 10-20 year is $50 \%$. The long period of cultivating experience on pineapple farming because farmers already doing cultivation on pineapple since the age of 14 years old and this farming already became as second generation.

Table 1. Description of Pineapple Small Farmers in the Study Area

\begin{tabular}{cccc}
\hline No & Characteristic & Description & Percentage (\%) \\
\hline 1 & Education & Elementary School & 24 \\
& & Junior High School & 52 \\
& Age & Senior High School & 24 \\
& & $25-40$ & 21 \\
& & $41-55$ & 62 \\
& & $>56$ & 17 \\
3 & Pineapple Farmer Experience on & & \\
& cultivating (year) & $0-10$ & 7 \\
& & $10 .-20$ & 50 \\
\hline
\end{tabular}

Source: Own survey, 2019

\section{Farmer's Income and Factors Affecting the Farmer's Income}

Income is something that is needed by farmers to meet their family cost, the income of the small farmer pineapple in Tangkit baru village can be seen in the table 2 . 
Table 2. Pineapple Small Farmer' Income

\begin{tabular}{cccc}
\hline No & Variable & Unit & Average \\
\hline 1 & Field scale & Ha & 1.96 \\
2 & Yield & Pieces/month & 1378.8 \\
3 & Price & IDR & 2530 \\
Total revenue of small farmer & IDR/month & 3488364 \\
\multicolumn{2}{c}{ Total Cost of pineapple farming } & IDR/month & 532250 \\
Income of small farmer & IDR/month & 2956114 \\
\hline
\end{tabular}

Source: Calculation data processing, 2019

Furthermore, there are seven variables that are thought to affect the income of independent small farmers in the study area. The selection was made based on observation in the study area, there were differences made during the process of cultivation of pineapple and from previous study revealed by (Diantoro, Sunarsih, and Soejono, 2009) [1].

The initial step was finding the requirements of normality, multicollinearity, and heteroscedasticity tests. The distribution of normality tests was intended to determine the normal distribution of data in the studied variables, the normality test showed that the study data was normally distributed with Asymp values Sig. (2-tailed) 0.200, This shows that value is over 0.05 , this shows that the data is normal. Multicollinearity tests showed that there are no independent variables that have a VIF value $<10$ and tolerance value $>0.10$.

Thus it can be ascertained that the data does not occur multicollinearity and is normal, it can proceed to the next test with heteroscedasticity tests, the values got consecutively from the independent variables are 0.500, 0.215, 0.204, 0.769, which from all the values got from the table coefficient or the Sig. over 5\% (0.05), This shows that the data does not occur heteroscedasticity and normal. After all data normally distributed, then proceed with multiple linear regression, and based on the analytical tool used 4 independent variables which can be analyzed further to determine the effect of these variables on farmers' income, then variables that cannot be included in the model are X5, X3, X2. The variables are constants or have missing correlations. Based on the 4 variables performed the multiple regression analysis shows that independent variables affect the dependent variable (income), the results of the analysis can be seen in table 3 .

Table 3. Analysis Result

\begin{tabular}{ccccc}
\hline Model & $\mathrm{R}$ & R Square & Adjusted R Square & Std. Error of the Estimate \\
\hline 1 & $.901^{\text {a }}$ & 0.811 & 0.781 & 10817499.37 \\
a Predictors: (Constant), field scale, land rent, labor, fertilizer & \\
b. Dependent Variable: $Y$ & & \\
\hline
\end{tabular}

Source: Statistical data processing, 2019

Table 3 show that all variables can explain that there is an influence on the income of 78.1\%, while $21.9 \%$ is explained outside the variable that is set. Based on the results of ANOVA analysis shows that the model got as a whole has the significant effect on the income of pineapple small farmers, then results of ANOVA analysis can be seen in table 4 . 
Table 4. ANOVA Analysis Results

\begin{tabular}{ccccccc}
\hline Model & Sum of Squares & $\mathrm{df}$ & Mean Square & $\mathrm{F}$ & Sig. \\
\hline 1 & Regression & $1.25639 \mathrm{E}+16$ & 4 & $3.14 \mathrm{E}+15$ & 26.842 & $.000 \mathrm{~b}$ \\
& Residual & $2.92546 \mathrm{E}+15$ & 25 & $1.17 \mathrm{E}+14$ & & \\
Total & $1.54894 \mathrm{E}+16$ & 29 & & & \\
& & & & & \\
a Dependent Variable: Y & & & & & \\
b Predictors: (Constant), X7, X4, X6, X1 &
\end{tabular}

\section{Source: Statistical data processing, 2019}

Moreover, to ensure that the independent factor influences the dependent factor, based on table 4 can be seen the results of the $F$ test that the calculated $F$ value is $26,842>2.75871$ ( $F$ table) and the Sig value $0.000<0.05$, then the independent variable is found in the model together affecting the income of small farmers. Partially, based on the results of the T-test analysis, there are two variables that have a significant effect on the income of pineapple small farmer in Tangkit baru village. The results of the T-test can be seen in table 5.

Table 5. Coefficients Analysis Results

\begin{tabular}{|c|c|c|c|c|c|c|}
\hline & \multirow[t]{2}{*}{ Model } & \multirow{2}{*}{$\begin{array}{c}\begin{array}{c}\text { Unstandardized } \\
\text { Coefficients }\end{array} \\
\text { B }\end{array}$} & \multicolumn{2}{|c|}{ Standardized Coefficients } & \multirow[t]{2}{*}{$\mathrm{t}$} & \multirow[t]{2}{*}{ Sig. } \\
\hline & & & Std. Error & Beta & & \\
\hline \multirow{5}{*}{1} & (Constant) & 19075125.03 & 7973973.639 & & 2.392 & 0.025 \\
\hline & $\mathrm{X} 7$ & 12477488.11 & 5350498.414 & 0.389 & 2.332 & 0.028 \\
\hline & X6 & 15.999 & 2.702 & 0.748 & 5.921 & 0.000 \\
\hline & $\mathrm{X} 4$ & -2.151 & 2.689 & -0.072 & -0.8 & 0.431 \\
\hline & $\mathrm{X} 1$ & -1.169 & 0.975 & -0.207 & -1.198 & 0.242 \\
\hline
\end{tabular}

\section{Source: Statistical data processing, 2019}

The variables that have significant effects are:

\section{Field Scale (X7)}

The field scale of farmers has a significant effect on income, this can be seen from the value of sig is $0.028<\alpha(0.05)$, this is in line with Handayani (2006) [4] stating that a relatively narrow control of land will impact crop yield efficiency. Farmers who only own and work on the narrow land will not produce optimally, then farmers will receive income less of harvest benefit compare with the total farming costs. In addition, results of the field survey found that farmers in the Tangkit baru village on average only have less than 3 ha of land, and if the farmers want to buy land for land expansion, farmers unable to buy the new land because the price of land is very expensive, also farmers have the limitation of capital.

\section{Labor Factors (X6)}

The labor (X6) of farmers has a significant effect on income, this can be seen from the value of sig is $0,000<\alpha(0.05)$. Labor factor it was found that has a significant effect on income from small farmers, based on direct field survey to the study area and interviews with respondents, the farmers said that they did not use labor from outside of study area or hired labor from outside the family labor, in their analogy, if they only have land less than $2 \mathrm{Ha}$, they can handle farming without labor from outside. Unfortunately, when peak harvest season pineapple harvested is not optimal or pineapple stay overnight on the field and not have time to sell, this is decaying a crop production loss, because the lack of labor for effective in harvesting pineapple, but farmers are still indifferent with this problem.

Reaffirmed in Todaro (2000) [9] states that population growth and labor growth are considered as one of the positive factors that spur economic growth. The greater number of workers means that it will increase the level of production in an agricultural business. 
Variables that have no significant effect on income are the Land rent (X4) and fertilizer (X1), the Land rent (X4) and the fertilizer (X1) have no significant effect on income of the farmer, because only a few small farmers do these activities (X4) and not optimal (X1), and only farmers with land ownership of less than 1 hectare carry out this activity (X4), farmers who own more than 1 hectare of land are not because farmers are able to buy new land, but this land is inherited from their parents, and farmers manage their pineapple farming improperly and does not implement the recommended guidance of planting that has been recommended by the local agricultural service including in fertilizing (X4), also this result is in line with previous research conducted by (Zargustin, Siswati and Mufti, 2013) [10] with other agricultural commodity (rice farming), only the area of land which has a significant effect on the income of pineapple farmers.

\section{CONCLUSION AND RECOMMENDATION}

Based on the results and discussion, it can be concluded that from 7 variables used to determine the effect on income, there are only 4 variables that can be analyzed further. Variables that significantly influence the income of pineapple small farmers in Tangkit baru village are field scale (X7) with a significance value of 0.028 and labor (X6) with a significance value of 0.000 .

From the results can be made recommendations that it is important for farmers to create a cooperative to apply for loans (capital) to banks for expand pineapple farming land. This is aimed to increase farmer's income to meet the needs of life and education of farmers' children.

Then, fitting farmers to use labor adequate to assist pineapple farming activities, especially during peak pineapple harvests season, where farmers prefer to do pineapple harvesting only by relying on labor from families that aim to reduce labor costs, but harvesting activities become ineffective and result in pineapple harvesting late and often rot before it is sold, then affecting the quality and the effect this decision is low selling price that small farmers will get.

\section{References}

Diantoro, K., Surnasih, and Soejono. (2009). Faktor-Faktor yang Mempengaruhi Produksi Padi pada Kelompok Tani Patemin Kecamatan Tlogosari Kabupaten Bondowoso. Jurnal SEP, 3(3), 55-60.

Gujarati, N. (2006). Basics of Econometrics. (3rd ed.), Jakarta: Erlangga.

Hadiati, S. and Indriyani, N.L.P. (2008). Petunjuk Teknis Budidaya Nanas. Balai Penelitian Tanaman Buah Tropika.

Handayani, D.M. (2006). Analysis of profitability and income of rice farming according to area and land ownership status in Karacak Village, Leuwiliang Sub-District, Bogor Regency. Bogor: Press of Bogor Agricultural University.

LIPI. (2014). Modul Diklat Jabatan Fungsional Peneliti Tingkat Pertama: Pengolahan Dan Analisis Data. Cibinong: LIPI.

Nazir, M. (2005). Research Methods. Bogor: Ghalia Indonesia.

Pratama, A. (2017). Social Capital on Bugis Ethnic Agribusiness Development: Study Cultivating Pineapples in Tangkit Baru Village Sub District of Sungai Gelam District Muaro Jambi in Jambi Province, Padang: Press University of Andalas.

Soekartawi (1995). Analysis of Farming, Jakarta: Press University of Indonesia.

Sudrajat, M. (1985). Mengenal ekonometrika Pemula. Bandung: Armico

Todaro, P. M. (2000). Pembangunan Ekonomi di Dunia Ketiga. Jakarta: Erlangga.

Zargustin, D., Siswati, L., dan Mufti, (2013). Strata Penguasaan Lahan Dan Pendapatan Usahatani Padi Sawah Serta Hubungannya Dengan Alokasi Waktu Kerja Di Luar Usahatani, Studi Kasus: Desa Pulau Birandang Kecamatan Kampar Timur Kabupaten Kampar. Riau: Press of Lancang Kuning University. 